\title{
Миодраг Јовановић
}

\section{ФИНАЛНЕ СЕКВЕНЦЕ ОД ДВА РАЗЛИЧИТА ВОКАЛА У ЦРНОГОРСКИМ НОВОШТОКАВСКИМ ГОВОРИМА}

Досад у дијалектолошким радовима - ни у оним старијим, ни у монографијама које приказују савремено стање - нијесу уцртане прецизне изоглосе простирања одређених појава које се тичу судбине вокалских група -ao, -yo, -ео и -ио на крају ријечи. То смо овим радом у првом реду поставили као задатак.

Кључне ријечи: регресивна асимилација, прогресивна асимилација, вокалска група, несажета скупина, акценат, секундарни сугласник, хијат, дијалекат, говор, монографија.

Мања заступљеност финалних вокалских група, усљед уједначавања артикулације у правцу првог (прогресивна) или у правцу другог вокала (регресивна), одавно је примијећена тенденција у дијалектима српског језика. При томе, неки сљедови вокала, нарочито секвенца -aо, израженије су склони промјенама - у резултату до краја доведеног процеса асимилације, као једног од начина укидања хијата, најчешће је дуг самогласник, без обзира да ли се сажимају дуги или кратки самогласници. С друге стране, то никако не значи да асимилациони процеси имају изглед потпуно стабилизоване појаве, зато ћемо у нашем раду утврђивати и разлоге (прозодијске, семантичке и др.) који су у црногорским новоштокавским говорима понекад погодовали очувању неизмијењених вокалских група. А судбину вокалских група у сјеверозападној Црној Гори значајно је сагледати и у ширим дијалекатским оквирима: прогресивни говори источнохерцеговачког типа налазе се и на србијанској, и на босанско-херцеговачкој, и на хрватској страни - са којима структурно-типолошки и генетски чине недјељиву цјелину; а и због додира са говорима зетско-јужносанџачког дијалекта, са битно другачијим резултатима сажимања вокала на крају ријечи - нарочито секвенце -ао (као рефлекса старијих финалних група -ал и -ьл). 
Јасно је да судбина финалне вокалске скупине -ао (у највећем броју примјера настала промјеном сонанта $\pi>o$ на крају слога), због фреквентности категорија ријечи у којима се јавља и с примјетном колебљивошћу у дистрибуцији, има карактер најинтересантније појаве.

Испитивачи говора сјеверозападне Црне Горе, дакле новоштокавских говора, утврдили су да се вокалска група -ао на крају ријечи, без обзира да ли је акцентована или неакцентована, углавном свела на вокал -o. Регресивну асимилацију - $а о>0$ - у ликовима радног глаголског при-

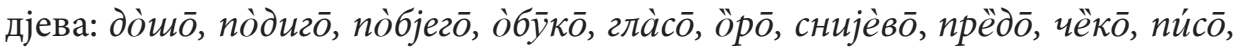

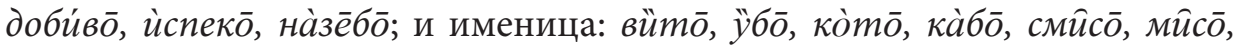

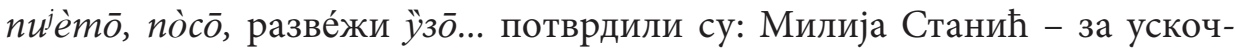
ки, Јован Вуковић - за говоре Пиве и Дробњака, Мато Пижурица - за околину Колашина, Драго Ћупић - за град Пљевља и његово окружење, Данило Вушовић у дијалекту источне Херцеговине - прецизније у говорима Бањана, Грахова, Рудина и Голије ${ }^{1}$. Изложена црногорска ситуација сагласна је, понекад готово до детаља, са већином сродних говора у окружењу - србијанским и босанско-херцеговачким². Контракција вокалске

${ }^{1}$ Милија Станић, Ускочки говор, СДЗб ХХ, Београд 1974; Јован Вуковић, Говор Пиве и Дроюака, ЈФ XVII, Београд 1938-1939; Мато Пижурица, Говор околине Колашина, ЦАНУ, Пос. издања, књ. 12, Одј. умјетности, књ. 2, Титоград 1981; Драго Ћупић, Основне особине говора Пљеваља, ЦАНУ, Гласник Одјељења умјетности 8, Титоград 1988; Данило Вушовић, Диалект источне Хериеговине, СДЗб ІІІ, Београд 1927.

2 Уједначавање артикулације финалне секвенце -aо у правцу другога члана:

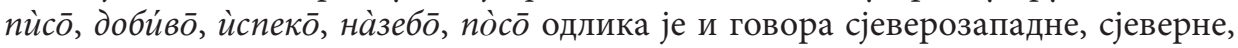
сјевероисточне, централне, југоисточне и југозападне Босне (Драгомир Вујичић, Фонетске особине говора сјеверозападне Босне, књига II, Институт за језик и књижевност у Сарајеву, Одјељење за језик, Сарајево 1979, 11-157; Фонетске особине говора сјеверне и сјевероисточне Босне, књига V, Сарајево 1985, 11-171; Фонетске особине говора иентралне, југоисточне и југозападне Босне, Босанскохерцеговачки дијалектолошки зборник VI, Институт за језик и књижевност, Сарајево 1990, 7-125; Џевад Јахић, Ијекавскочтокавски говори источне Босне, Босанскохерцеговачки дијалектолошки зборник, књига VIII, Сарајево 2002, 52) и источне Херцеговине (Асим Пецо, Говори источне Хериеговине, СДЗб XIV, Београд 1964, 41). У сажимању вокалске групе -ао са говором Пиве и Дробњака слагали би се и западнији (гатачки) - наглашава Јован Вуковић (стр. 29).

Судбином секвенце -ао црногорски новоштокавски говори чине једну цјелину и са прелазним (и)јекавско-екавским говорима у Србији, као што су: говори србијанског Полимља и новопазарско-сјенички говори, па нешто јужније и са бихорским говором (Мирослав Николић, Говори србијанског Полимљь, СДЗб XXXVII, Београд 1966, 213; Данило Барјактаревић, Новопазарско-сјенички говори, СДЗб XVI, Београд 1966, 47-49; Данило Барјактаревић, Бихорски говор - Фо- 
групе -aо > -о по правилу не изостаје ни у сјеверозападној Боки - дакле у црногорским приморским говорима херцеговачког типа ${ }^{3}$. А мора се имати у виду да је говорна зона од Пераста, односно од замишљене граничне линије између зетско-јужносанџачких и новоштокавских приморских говора до границе са Хрватском још увијек недовољно испитана. Овим се простором - у радовима са другачијом тематиком - бавио Срђан Мусић ${ }^{4}$, приближно са овог простора имали смо увид и у грађу из говора Лепетана, коју је четрдесетих година прошлог вијека сакупио Васо Томановић ${ }^{5}$, гдје се налазе потврде само за регресивну асимилацију:

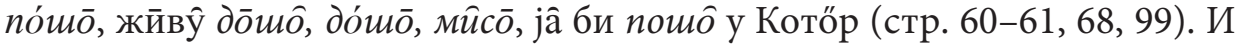
идући даље ка западу, у говорима Хрватског приморја, према материјалу који су дијалектолози дали из Дубровника, Цавтата и Конавала' ${ }^{6}$ група

нетске особине и акиенат, ЗбФФП ІІІ (1966), 31-32; Радосав Ђуровић, Реблекси јата у околини Прибоја, СДЗб XXVI, Београд 1980, 265). И још даље - у говору Горобиља (Мирослав Николић, Говор села Горобиља (код Ужичке Пожеге), СДЗб XIX, Београд 1972, 657), па и у говорима косовско-ресавског типа (на примјер, Радоје Симић, Левачки говор, СДЗб ХІХ, Београд 1972, 152, гдје се прогресивна асимилација -ао > - а своди у ствари само на појединачне случајеве).

3 Много интересантнију слику пружају црногорски приморски говори зетско-јужносанџачког типа - на примјер, у говорима Мрковића, Спича и Паштровића асимилациони процеси у рефлексима старих вокалских група -aл, -ьл на крају ријечи у високом степену зависе од поријекла првог члана секвенце. Зато

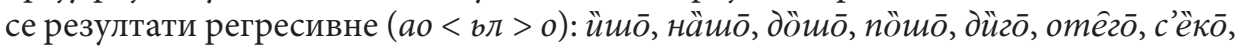

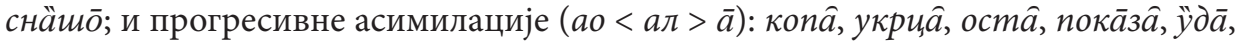
кӱпов $\bar{a}, n \bar{u} т \hat{a}, n о ̈ ш т о в \overline{~ н а л а з е ~ и ~ у ~ и с т о м ~ г о в о р у ~-~ о ~ т о м е ~ с м о ~ п и с а л и ~ у ~ р а д у ~ В о-~}$ калске групе на крају ријечи у говорима Црногорског приморја, Зборник радова са научног скупа одржаног на Филолошко-уметничком факултету у Крагујевцу (31. X - 1. XI 2006), Српски језик и друштвена кретања, књига 1, 81-97.

4 Романизми у северо-западној Боки Которској, Филолошки факултет Београдског универзитета, књ. XLI, Београд 1972.

5 Акценат у говору села Лепетана (Бока Которска), ЈФ XIV, Београд 1935. Иако говор Лепетана, и територијално и структурно, припада старијим црногорским говорима, ипак се по неким особинама - због близине са новоштокавским говорима - може сматрати у извјесном смислу прелазним зетско-херцеговачким говором.

${ }^{6}$ Перо Будмани, Дубровачки дијалекат, како се сада говори, Рад JA3У, LXV, Загреб 1883, 156; Милан Решетар, Der štokavische Dialekt, Keiserliche Akademie der Wissenschaften, Schriften der Balkankommission VIII, Wien 1907, 108; Далибор Брозовић, Цавтат, Фонолошки описи сх/хс, словеначких и македонских говора обухваћених Општесловенским лингвистичким атласом, Посебна издања АНУБиХ, књ. XV, Одјељење друштвених наука, књ. 9, Сарајево 1981, 499; Павле Ивић, Дијалектологија српскохрватског језика, Увод и штокавско наречје, Ма- 
- ао сажима се у - $\bar{o}$. Чак и у икавским говорима, који се налазе у њиховом сусједству, зијев који настаје при изговору ове вокалске скупине на крају ријечи отклања се асимилацијом у корист другога члана: пёко̄, кӧво̄, npö$\partial \bar{o}^{7}$.

Да ситуација у црногорским говорима источнохерцеговачког типа није посве идилична, показују поједини говори у којима се, напоредо са -aо > -о, чују и резултати прогресивне асимилације, нарочито у близини територије зетско-јужносанџачког дијалекта. Наиме, још је Данило Вушовић писао да се у мјестима ближе околине Никшића (села никшићког поља и жупе) ова два вокала сажимају обично у дуго $a$ : $\partial \grave{m} \bar{a}$,

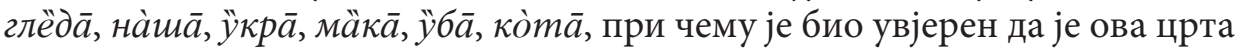
дошла из јужнијих црногорских говора ${ }^{8}-$ са асимилацијом -aо $>-a$ као једином могућности. Истог је поријекла, како сматра Јован Вуковић, деценију-двије касније, и појава - $a о>-a$ у јужнијим дробњачким и пивским селима Мокром, Милошевићима и Брезнима - што ближе говорима Никшићког поља, то је сажимање у - $а$ досљедније спроведено9. Иако, како сам признаје, није успио да тачно утврди границе простирања ове појаве, ипак је истакао да, идући даље ка унутрашњости Пиве и Дробњака, све више превладавају резултати регресивне асимилације. Тако је на примјер већ у пивском селу Безују и дробњачком Дубровску у мањој мјери распрострањена асимилација - $a+-o>-a$, тј. остала је везана искључи-

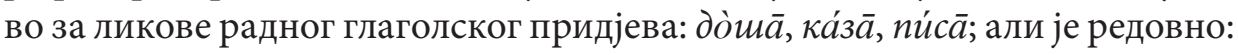
ко̀то̄, ӱзо (узао) и сл. (Говор Пиве и Дробюака, 20-21). Чуди, међутим, што је у неким сјеверним дробњачким селима, као што је Његовуђа, спорадично биљежено -ао > - $a$ - вјероватно зато, закључује Ј. Вуковић, што његовућка села у планини Сињајевини имају катуне у сусједству са Бјелопавлићима ${ }^{10}$.

тица српска, Нови Сад 1985, 138-139; Зорка Кашић, Говор Конавала, СДЗб XLI, Београд 1995, 265; Јосип Лисац, Хрватска дијалектологија, Golden marketing Tehnička knjiga, Загреб 2003, 107.

7 Павле Ивић, Дијалектологија српскохрватског језика, 200.

8 Данило Вушовић, Диалект источне Хериеговине, 13.

9 Јован Вуковић, Говор Пиве и Дробюака, 20-21.

10 У науци о језику бјелопавлићки говор се дефинише као прелазни говор зетско-херцеговачког типа у који допиру изоглосе новоштокавских говора, али исто тако, гушћим сноповима изоглоса, и особине говора зетско-јужносанџачког типа - једна од њих свакако је вокал $а$ као резултат асимилације некадашњих вокалских група -ьл (ово је говор у којему је континуант полугласника у јаком

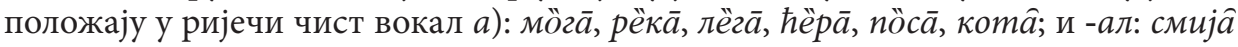

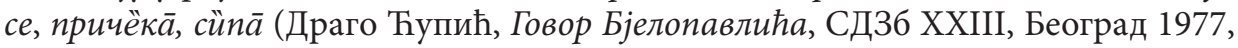


Један други испитивач дурмиторских говора, Милија Станић, не слаже се са објашњењем: „Ова претпоставка за села какво је Његовуђа не може опстати, јер се бјелопавлићки катуни налазе на крајњем истоку планине Сињајевине - 20 до 30 км далеко од његовућког краја. Између Његовуђе и ових катуна налази се читаво једно раније црногорско племе - Шаранци. Објашњење зашто се у области Његовуђе сусреће - $\bar{a}$ од -aо треба тражити на другој страни - можда су досељени из крајева у којима је асимилација -ao > - а редован процес или је у питању нешто друго - сматра Милија Станић ${ }^{11}$. Осим тога, по мишљењу овог дијалектолога, Вуковићева претпоставка не може опстати ни због још једне чињенице: ускочки катуни на планини Сињајевини, иако се граниче са бјелопавлићком испашом, нијесу под директним утицајем сињајевинских Бјелопавлића - удаљеност између најближих катуна Бјелопавлића и Ускока већа је од 10 км. Због тога Ускоци из ових катуна никад немају -ao > -a, већ увијек -о (Ускоци, 39$)$.

Но, асимилацију у правцу вокала $а$ имамо и у самим Ускоцима, али у неким другим мјестима: у ускочким селима Стругу и Малинском, насељеним живљем које се доселило из околине Никшића или из неког другог црногорског краја са асимилацијом -ao > $-a$, од истих особа чује

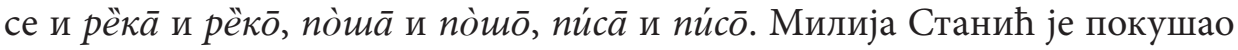
да утврди и прецизну изоглосу простирања појаве - „северну границу ове црте у ускочком говору чине реке Тушиња и Буковица, низводно од места где се у њу улива Тушиња" 12 . На питање шта ће у овим селима превладати - староцрногорска или источнохерцеговачка варијанта - Станић сматра да ће се ствар окончати у корист новоштокавске - jep је -ao > -o редовна црта у свим селима сјеверно од поменуте границе.

Резултате прогресивне асимилације, највјероватније као утицај зетско-јужносанџачког дијалекта, у најисточнијим црногорским новоштокавским говорима забиљежио је и Мато Пижурица ${ }^{13}$ : приликом његове посјете селима Кути, Горња Бијела и Старче (прво је у Никшићкој жупи, друго је најзападније дробњачко село, а Старче је у Горњој Морачи) констатовано је редовно или врло често сажимање вокалске групе -ао у $-\bar{a}-$ и то у Кутима и Горњој Бијелој досљедно, а у горњоморачком селу

18). Од говора изван граница Црне Горе прогресивну асимилацију налазимо на сјеверозападу територије источнохерцеговачког дијалекта у личко-сјевернодалматинској зони, југозападној Босни, Кордуну, Жумберку, главнини говора Баније и Горском котару (Јосип Лисац, Хрватска дијалектологија, 100).

${ }_{11}$ Милија Станић, Ускочки говор, 39.

${ }_{12}$ Милија Станић, Ускочки говор, 18.

13 Мато Пижурица, Говор околине Колашина, 75. 
Старчу спорадично. Још су више у околини Колашина видљиви резултати прогресивне асимилације у непосредном сусједству са васојевићким подручјем - нпр.: ка̂ кӱчка, снаша̂ ce, доша̂ да̀нас (Јабука - мало село код извора Таре, ниже од Матешева); ко е рёка̄, даิ сам јој (Падеж - заселак села Речина) ${ }^{14}$. За разлику од прилика у неким ускочким селима, гдје ће се колебање између прогресивне и регресивне асимилације вјероватно разријешити устаљивањем резултата регресивне, у околини Колашина истичу се другачије тенденције: „У говору млађих генерација изгледа да сажимање групе -ao > $-\bar{a}$ узима све више маха, што је посљедица све снажнијег утицаја Подгорице као културног, школског и административног центра" (Колашин, 75).

За проширивање знања о асимилацији вокалске групе -ао на крају ријечи у најисточнијим црногорским новоштокавским говорима потребни су нови дијалектолошки радови - нарочито из околине Мојковца и Бијелог Поља. А на основу досадашњих чини се да се непосредни до-

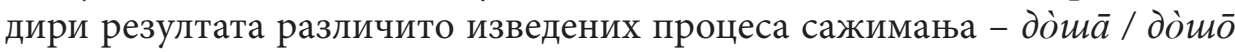
дешавају у близини обала ријеке Лима ${ }^{15}$.

Необична је појава, али ипак готово у свим говорима потврђена, да вокали $a$ и $о$ на крају ријечи остану и несажети. А такви се примјери: спре́мао ce, ста̀jao, зӓсnаo, пјёвао, сми́јао се обично објашњавају прозодијским, семантичким, а понекад и неким другим разлозима. У грађи из говора Лепетана нешто израженије чување неизмијењене вокалске групе -ао на крају ријечи омогућио је акценат: држӓо, боја̄о се (92), оружӓо (95), глођӓо, зобӓо, локӓо, пеньӓо, стенай, чешӓо (97), ревӓо, куповӓо, боловӓо, путова̋о, робовӓо, туговӓо (98). Иначе је, ван случајева када је вокал $а$ акцентован, и у овом говору веома ријетко очувана: лёгао (90), сми́јао се (97), р̈вао, рёкао (98), мйсао (68). Како је у говорима сјеверозападне Црне Горе, у вишесложним ријечима, вокал $а$ увијек неакцентован (краткосилазни акценат досљедно је у политонијском духу повучен на претходни слог: боловӓо > боло̀вао), то је могућност реализације вокала $a$ и $o$ једног поред другога још више смањена. Процеси -ao > -o, уколико први вокал из секвенце није акцентован, скоро никако не изостају ни у сродним говорима Хрватског приморја (Конавли, 265; Цавтат, 499) ни у босанско-херцеговачким говорима (Д. Вујичић, Фонетске особине говора централне, југоисточне и југозападне Босне, 31) - поред доста необичног, али потврђеног: пјёвао, сми́јао се.

${ }_{14}$ Иcmo, 75.

15 Момир Секулић, Неке особености говора Бијелог Поља, часопис Токови, Иванград 1971, 167. 
Из јединствене слике црногорских новоштокавских говора судбином вокалске групе - ао на крају ријечи издвајају се двије лексеме - nàкао и оेрао - које, поред најчешће несажете варијанте и нешто рјеђе асимиловане -ao > -o, у дијалекту источне Херцеговине још могу да гласе $n a ̀ \kappa \bar{a} j$ и $\grave{o} \bar{a} j$ - како је тридесетих година прошлога вијека чуо испитивач ове говорне зоне Данило Вушовић (òpāj те пӧнио - за кокошку $)^{16}$. То не значи - сматра он - да се овдје глас л (од па̀кал, òрал) на крају ријечи развио гласовним путем у $j$, већ је прије добијен према примјеру раิj или онако као што се у неким дијалектима добија $j$ у оррај (< орах), према множини opaju; а не вјерује у могућност да је ту додата партикула ${ }^{17}$.

А посебно асимилација није лака у лексемама које се састоје од два слога - поготово зато што је вокал $a$ у групи -ао увијек под краткосилазним акцентом који је довољно јак да се у великој мјери супротстави контракцији. Осим тога, изгледа да се те кратке форме: пäо, знӓо, брӓо, nрäo, cmäo, жäo, däo, кла̋o тешко дају, без штете по значење, сводити на још краће - чак у говору Пиве и Дробњака у двосложним ријечима никако и нема сажимања: jäo (jaxao), кра̋о, дäo, знӓо и сл. ${ }^{18}$ Међутим, у другим говорним зонама сјеверозападне Црне Горе опирање општој гласовној појави асимилације у правцу другога вокала није толико чврсто ни у двосложним облицима - штавише, у свим су мјестима, поред несажетих, присутне и асимиловане форме: напоредо доि и дӓо, зноิ и знӑо, броิ и брӓо итд. Стиче се утисак да се у појединим зонама у правом смислу може говорити о равноправној употреби сажетих и несажетих. Уз то, у дијалекту источне Херцеговине, напоредо са очуваном вокалском групом, те облицима са извршеним сажимањем у правцу другога вокала, Данило Вушовић наводи и двосложне ријечи у којима је, као резултат утицаја старијих црногорских говора, извршена прогресивна асимилација: жа̂,

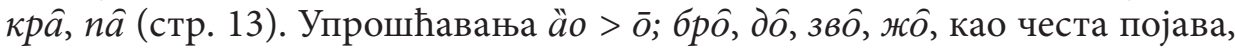
сусрећу се и у новоштокавским говорима изван Црне Горе - у говорима Хрватског приморја (Конавли, 265; Цавтат, 499 - ипак, од дублета са сажетом и несажетом формом типични говорник ће радије одабрати

16 Данило Вушовић, Диалект источне Хериеговине, 23.

17 Исто, 23.

${ }_{18}$ Јован Вуковић, Говор Пиве и Дробюака, 20. При том је осјећао да сусједни говори Мораче и Колашина нешто израженије него пивско-дробњачки врше сажимање вокалске групе - $а$ - и у случајевима када је $a$ под акцентом; са свим размишљањима Ј. Вуковића сагласан је истраживач говора околине Колашина Мато Пижурица (стр. 74), а потврдили су их у говору Роваца и каснија истраживања Драгољуба Петровића (Гласовни систем ровачког говора, ЗбФЛ IX, Нови Сад 1965, 164). 
сажету), говорима на тромеђи Црне Горе, Србије и Босне и Херцеговине (мада су у србијанском Полимљу неупоредиво распрострањенији и фреквентнији ликови типа: да̋o, жӓо, звӓо, зна̋о, пӓо ${ }^{19}$ ) и другим источнохерцеговачким говорима - према грађи коју су дали Драгомир Вујичић, са терена сјеверне, централне, југозападне и источне Босне ${ }^{20}$, и Асим Пецо из источне Херцеговине (стр. 42). Чак и у околним икавским говорима контракција -ао > - $\bar{o}$ мјестимично обухвата и двосложне облике: $\partial \hat{o}, ж \hat{~(П а в л е ~ И в и ћ, ~ Д и ј а л е к т о л о г и ј а, ~ 176) . ~ П о р е д ~ с в е г а, ~ и з г л е д а ~ д а ~}$ у свим говорима постоје неке лексеме које се упорније супротстављају асимилацији, заправо готово је искључиво пӓо, зӓо, крӑо, стӓо..., а веома необично поे, кроे, зоิ, стоิ и сл.

Изречене оцјене о секвенци -ао у двосложним облицима ремете се уколико се неки од тих ситних облика нађе у некој акценатској цјелини, тј. ако се испред њих нађе нека ријеч у проклитичкој функцији, контрак-

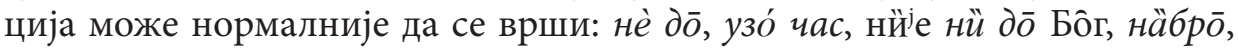

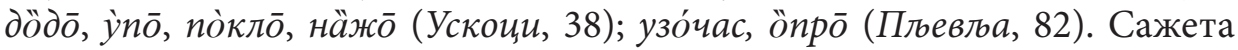
форма зоิ у говорима околине Колашина у изразима типа: $\grave{y}$-зо̄-чӓс, $н \grave{a}-$

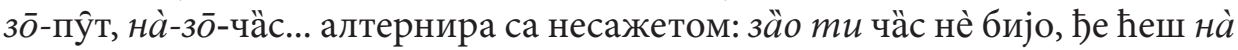
зао пуेт (Говор околине Колашина, 74). Такође и говор Пиве и Дробњака, који се највише опире сажимању вокалске групе -ао у двосложним ријечима, у овим позицијама одступа од изречене тенденције: је ли Боิг $\partial \bar{o}$ ко о̀д Босне̄, нё до̄ ми ђѐво̄јку (стр. 20).

Нема сумње, наша истраживања и увид у грађу из испитаних говора показују да повећање броја слогова у ријечи помаже асимилацију. Но, процеси су могли отићи и другим путем: у говору околине Колашина највише је примјера који се са нашом оцјеном не слажу - промјена - ао > -о у зӓдао, йздао, за̀nаo, до̀nаo (потврђено у свим мјестима) ипак се није извршила, а ову појаву Мато Пижурица тумачи подршком основних, како смо видјели врло често несажетих форми: дӑо, знӑо, пӓо и сл. (стр. 74).

Вокали $a$ и $о$ израженије се налазе реализовани један поред другога у поредбеном везнику, односно прилогу као. Ипак, у овој обично ненаглашеној ријечи високе учесталости у употреби су и конкурентни фонетски и прозодијски ликови: далеко најчешћа варијанта $\kappa \bar{o} / \kappa o$, а у

19 Мирослав Николић, Говори србијанског Полимља, 214.

20 Ријетко је на овој територији у овим облицима развијање секундарних гласова в и ј: дӓво, пӓјо, а најнеобичније у везнику као који понекад може да гласи каво (Драгомир Вујичић, Фонетске особине говора иентралне, југоисточне и југозападне Босне, 31). 
појединим говорима и $\kappa \bar{a} / \kappa a$. На примјер, од црногорских новоштокавских говора прогресивна асимилација потврђена је у околини Никшића (Диалект источне Хериеговине, 13 - иначе је на осталом терену овог говора - у Грахову, Бањанима, Рудинама и Голији - као $>\kappa \bar{o}$ једина могућност) и Колашина - само изузетно: ка̂ кӱчка (стр. 73). Интересантно да за процесе као > ка више знају неки сродни говори у окружењу. У говору Конавала, у једном новоштокавском говору на Хрватском приморју, у којему се поредбена ријеч као никад не јавља у пуном облику, тешкоћа у изговору финалне скупине -ао отклања се на два начина: а) као > ко - уколико сљедећа ријеч почиње сугласником: коิ да је мӧја, ко̄ ме̂д; б) $\kappa a о>\kappa a-$ уколико се послије као нађе везник $u$ : ка u оेна, ка и превй путт, о̀старй ка ѝ ја̄ (Конавли, 266). Овакав начин укидања хијата Зорка Кашић и не сматра асимилацијом, већ елизијом - јер је у резултату процеса кратки вокал $a$. Пошто у горњим примјерима поредбена ријеч, везник и наглашена ријеч чине једну акценатску цјелину, то се у говорном низу заправо појављују три вокала који се упрошћавају губљењем вокала у средини: као $u>\kappa a$ (Конавли, 266). Истог су поријекла, и на исти начин објашњени, и примјери са тромеђе Србије, Црне Горе и БиХ: исто ка u шӱмар, ка и да̀нас, влаิсти су прӓтиле ка и свӓка̄ (Србијанско Полимље, 215). Рјеђи су, али добро засвједочени, и ликови са дугим $\bar{a}-\kappa a о>\kappa \bar{a}$; а онда је то несумњиво резултат прогресивне асимилације $(-\bar{a} o>-\bar{a})$, а не контракције вокала $o-\kappa a o>\kappa(o) a-$ стр. 218. Ријетке примјере као $+u>$

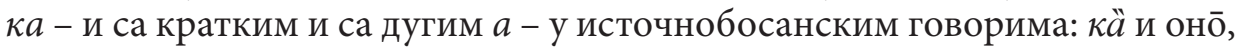
$\kappa a$ и сӓд, ка̂ и ср̈нда̄ћ неки дијалектолози ипак сматрају прогресивном асимилацијом - и то резултатом самосталног развитка ових говора, а отприлике је сличне учесталости и неизмијењена секвенца: као бра́на, као вӓтра, као вјётар ${ }^{21}$. Околина Колашина спорадично зна и за један за говоре херцеговачког типа необичан лик ки < као $u^{22}$ (стр. 74, фус. 100), при чему типични говорник из овог краја, како сматра Мато Пижурица, „никад не би употријебио као”. Иако као много необичнија варијанта од сажете, настала регресивном асимилацијом, неизмијењени лик као чује се и у дурмиторским говорима, тј. у говорима Пиве и Дробњака и Уско-

${ }_{21}$ Џевад Јахић, Ијекавскоштокавски говори источне Босне, 53.

22 Наслањање на везник $u$, тј. чешћа употреба везника $\kappa$, изражена је особина старијих црногорских приморских говора, а нарочито паштровског (Миодраг Јовановић, Говор Паштровића, Универзитет Црне Горе, Библиотека филозофско-филолошке науке, Подгорица 2005, 122-123); а процес као > кu, са малим бројем примјера, потврђен је и у средњокатунско-љешанским говорима (Митар Пешикан, Старочрногорски средюокатунски и љешански говори, СДЗб XV, Београд 1965, 125). 
ка, који заузимају једно од централних мјеста у склопу говора источне Херцеговине (Пива и Дробюак, 20; Ускоци, 39).

Како се из нашег приказа судбине вокалске групе -ао на крају ријечи може закључити, својом најчешћом варијантом -ao > $\bar{o}($ по̀mō, pëк $\bar{o}$, $\grave{u} m \bar{o}, \kappa \bar{o})$ црногорски новоштокавски говори много су ближи западнијим говорима, који се налазе у Босни и Херцеговини, Хрватској и југозападној Србији (србијанско Полимље) него онима црногорским зетско-јужносанџачког типа, југоисточно од замишљене линије која правцем сјеверозапад-југоисток дијели Црну Гору на два готово једнака дијела. Међутим, неки говори сјеверозападне Црне Горе показују знаке доста јаког утицаја архаичнијег црногорског дијалекта из којег се у поједине зоне Ускока, Пиве, Дробњака, околине Никшића и околине Колашина, противно општим тенденцијама, шире и резултати прогресивне асимилације (мада о разлозима продирања ове црте у црногорске новоштокавске говоре међу дијалектолозима има различитих мишљења). Отуда

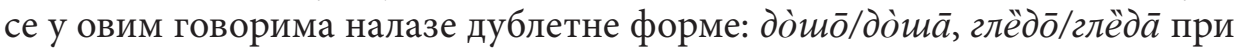
чему један исти говорник, уколико смо створили ситуацију за природни говорни ток, може употријебити обје варијанте - ову са упрошћавањем финалне секвенце у правцу вокала $а$ свакако много рјеђе.

Склоност промјени, али у много мањој мјери, у црногорским новоштокавским говорима показују и друге финалне секвенце: -уо и -ео; а тешкоћа у изговору два узастопна вокала може се отклањати и развијањем секундарних сугласника између вокала - нарочито у вокалској групи -ио.

Вокалска група -yo.

Судбином финалне секвенце -уо говори источнохерцеговачког дијалекта - и црногорски и они у сусједству - битно се разликују од зетско-јужносанџачких. Наиме, у архаичним говорима југоисточне Црне Горе секвенца -уо ријетко се уклања асимилацијом. А управо је то у већи-

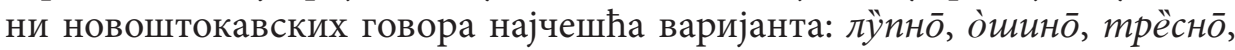

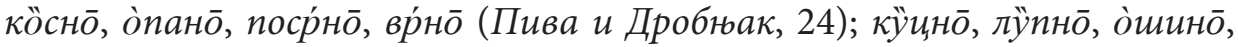
дйгно̄ (Диалект источне Херцеговине, 14) - посебно у западним мјестима овог дијалекта (у другом дијелу области, у никшићком говору, обичнији

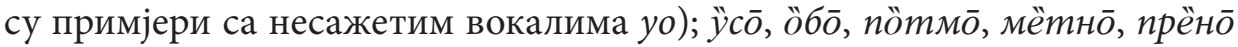
ce, зӓсо̄, прӧсо̄ (Асим Пецо, Говор источне Хериеговине, 44); вр́но̄, за̀zино̄,

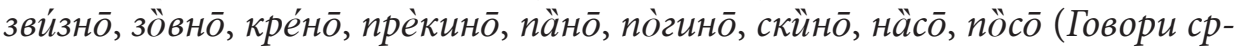
бијанског Полимъьа, 217-218; Ијекавскочтокавски говори источне Босне, 55). Додуше, и у овим говорима неизмијењену вокалску групу на крају ријечи чува акценат: чйо, трӱо - мада је често неизмијењена независно од тога да ли је први члан групе, вокал $y$, акцентован или није; а Јован 
Вуковић сматра да су то у Пиви и Дробњаку првенствено ријечи које су у реченици јаче наглашене: вр́нуо, поср́нуо, по̀гинуо..., док необично дјелује асимилација $y o>o$ у двосложној ријечи чйо > чоิ у дијалекту источне Херцеговине (стр. 14).

Интересантно, у говорима Ускока (43), околине Колашина (77) и Пљеваља (82) вокалска група -уо на крају ријечи увијек је неизмијењена - без обзира на мјесто акцента: трёснуо, ушти́нуо, а не трёсно̄, ушти́но̄. Изузетак су три села шире околине Колашина - Кути, Горња Бијела и

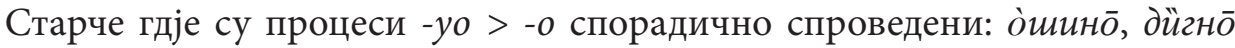
(стр. 13).

Судбином секвенце -уо црногорски новоштокавски говори се од зетско-јужносанџачких разликују још једном важном особином; у говорима југоисточне Црне Горе, тј. у „старијим” црногорским говорима, вокалска група -уо нешто се израженије разбија уметањем секундарног сугласника $j^{23}$. Од говора источнохерцеговачког типа избјегавање изговора сљедова вокала -уо на крају ријечи уметањем сонанта $j$ једино је потврдио Данило Вушовић у говору Опутних Рудина, између Никшића и Билеће: сӓзујо, чйјо, пӓнујо, ӧбујо, пӧгинујо, уммакнујо и сл. (Диалект источне Хериеговине, 22). У пограничним новоштокавским хрватским приморским говорима хијат се уклања развијањем сонанта в: пӓнуво, свр́нуво, чйво (Конавли, 285) и понекад у Цавтату: ѝзуво (Д. Брозовић, Цавтат, 499). У неким другим хрватским говорима - у Далмацији и Хрватском приморју - $\pi$ на крају слога прешло је у $a$, а коначни лик престилизације финалне секвенце -уо јесте -уја - сонант $j$ најприје се развио у сусједству палаталних вокала (по̀nuja, дйja, дебѐja), а затим је као готов формант пренесен и у позиције послије вокала задњег реда (чуја $)^{24}$.

Вокалска група -ео.

Нестабилна је и финална секвенца -ео, а испитивачи новоштокавских говора потврдили су три начина њене ликвидације: а) сажимање у

${ }^{23}$ Стрёкнујо, обӱјо, увенӱјо, пӓнујо (Михаило Стевановић, Источноирногорски дијалекат, Библиотека ЈФ V, Београд 1935, 30); чӥјо, погйнујо (Зета, Љешкопоље, Ријечка нахија - Драго Ћупић, Говор Бјелопавлића, 31); Лука Вујовић, Мрковићки дијалекат, СДЗб XVIII, Београд 1969, 190; Миодраг Јовановић, Говор Паштровића, 140-141; Бранко Милетић, Црмнички говор, СД3б IX, Београд 1940, 64, 124; Радомир Алексић, Извештај о испитивану спичанског говора, ГЗCBC VIII, Београд 1941, 20 итд. - а појаву дијалектолози овако објашњавају: аналогијом према бӥјо, вйдијо глас $ј$ је уопштен и у позиције између два вокала задњег реда $y$ и $о$, гдје се иначе гласовним путем никако није могао развити Данило Вушовић, Диалект источне Хериеговине, 22.

${ }^{24}$ Павле Ивић, Дијалектологија српскохрватског језика, 176. 
правцу другога члана вокалске групе - ӥзо̄, nёпо̄, зӓnо̄; б) развитак интервокалног ј између ова два вокала - ӱзејо, пёпејо; и в) најнеобичнија - развитак хијатског гласа в: ӱзево. Али примјери из многих говора потврђују и постојаност секвенце: зӓпочео, дѐбео и сл., а нарочито у кратким формама у којима је вокал $е$ под акцентом: клёо, мёо, плёо, свёо - очигледно, прилике су сличне онима са вокалском групом -ао на крају ријечи (näo, дäo, крӓо), те кратке форме тешко се своде на још краће, а осим тога процесе -ёо < -ёл > -о изразито спречава још и акценат (за разлику од вокалске групе -aо, гдје има и сажимања, у вокалској групи -ео изговор оба вокала је обавезан $)^{25}$. Нема код овако кратких облика ни развитка хијатских гласова $j$ и 8.

И укупно гледано у говорима сјеверозападне Црне Горе асимилација -ео > -о је најчешћи пут укидања хијата. Форме: $\ddot{y} з \bar{o}$, дӧн $\bar{o}, n o ̈ ч \bar{o}, д е ̈ б \bar{o}$,

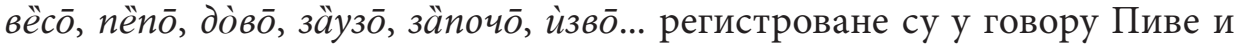
Дробњака (24), Пљеваља (82), Ускока (42), дијалекта источне Херцеговине (13), околине Колашина (14); а у истој мјери и у сродним говорима у окружењу: Конавли (266), Цавтат (499), у источној Босни (Џевад Јахић, Ијекавскочтокавски говори источне Босне, 55; Драгомир Вујичић, Фонетске особине говора иентралне, југоисточне и југозападне Босне, 31), србијанском Полимљу (216). Занимљиво, финална група -ео на исти је начин елиминисана и у говору Левча (пёпо, кӥсо, Раิнђо, вӥдо, зӓпо...) и другим говорима косовско-ресавског типа ${ }^{26}$, а исти резултат је дала и у прогресивнијим икавским говорима ${ }^{27}$.

Међутим, ови ликови у говорима сјеверозападне Црне Горе нијесу досљедни - у већини говора, напоредо са асимилованим, у употреби су и несажети, при чему се тешко могу одредити правила када ће један извор-

25 Необичан је у говору Ускока (стр. 42) примјер глоิ (< глёд̄̄ > гле̄ō послије испадања дентала $\partial$ гло)), а у напоредној су употреби и друге двије варијанте глёо и глёдо. Осим овог изузетка изговор групе ео у мёо, смёо, плёо, клёо је и у ускочком говору, и у другим говорима сјеверозападне Црне Горе, као и у другим новоштокавским говорима изван њених граница, обавезан - в. Говор Конавала, 266; А. Пецо, Говор источне Хериеговине, 43 итд.

${ }_{26}$ Радоје Симић, Левачки говор, 150; Асим Пецо, Бранислав Милановић, $P$ савски говор, СДЗб XVII, Београд 1968, 258; Радомир Алексић, Славко Вукомановић, Основне особине александровачког и бруског говора, АнФФ VI, 1962/63, 294-295; Данило Барјактаревић, Новопазарско-сјенички говори, 48; Данило Барјактаревић, Средюоибарска говорна зона, ЗбФФП II, Приштина 1964-1965, 97; Берислав М. Николић, Мачвански говор, СДЗб XVI, Београд 1966, 242-243; Душан Јовић, Трстенички говор, СДЗб XVII 1968, 44.

27 Павле Ивић, Дијалектологија српскохрватског језика, 176. 
ни представник новоштокавских говора изабрати неку од ових варијанти. Изузетак је говор Ускока, гдје је Милија Станић покушао да утврди правила - „ако се, с једне стране, погледају контраховане форме као:

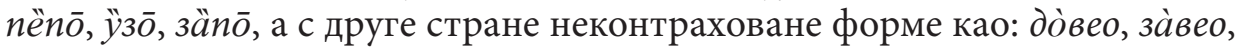
ùcnлео, òбрео запазиће се да контракција следи иза "акцента, а да је нема

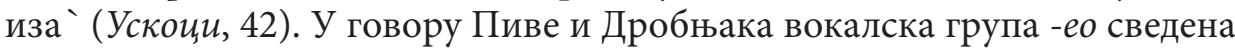
је регресивном асимилацијом на $\bar{o}$ (стр. 24$)$, а исту слику показује и дијалекат источне Херцеговине - једино у ближој околини Никшића ова вокалска група на крају ријечи остаје обично несажета: ӱзео, кйс'ео, дёбео, пѐпео (Диалект источне Хериеговине, 13).

У судбини -ео прилично су јасне сагласности са сусједним говорима у Босни и Херцеговини (Асим Пецо, Говор источне Хериеговине, 43; Џевад Јахић, Ијекавскочтокавски говори источне Босне, 55) - у објема зонама -ео $(<-e \pi)>-o$. С друге стране, у хрватским приморским говорима (Конавли, Цавтат и Дубровник) ${ }^{28}$ у употреби су и сажети и несажети

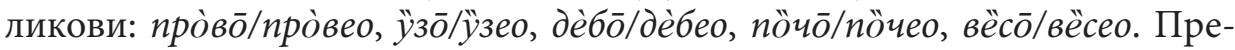
гледом грађе из говора Лепетана пронађени су само несажети: зӓпочео $(63,91)$, прѐузео, ӧбузео (92). И на крајњем новоштокавском југоистоку, у околини Колашина, слијед вокала -ео се не мијења - процеси сажимања: $n o ̈ ч \bar{o}, \ddot{y} з \bar{o}$ остају везани за села Кути, Горња Бијела и Старче (исто као -yo $>-o$ ) и уопште за досељенике из Горње Мораче (Говор околине Колашина, $14,76)$.

Нема у црногорским новоштокавским говорима уклањања хијата развијањем секундарног сугласника $j$ - за разлику од говора зетско-јужносанџачког типа, гдје ликови дебёјо, пёпејо, ӧплејо нијесу необични ${ }^{29}$. Аналошко $j$ између $е$ и $о$ јавља се у говорима источне Босне - чак и сонант в: ӱзево (Драгомир Вујичић, Фонетске особине говора централне, југоисточне и југозападне Босне, 31), који црногорским говорима није познат. Уметање j: ӱзејо, де́бејо забиљежено је и у Цавтату (Д. Брозовић, Цавтат, 499).

Говори источнохерцеговачког типа - и црногорски и говори у окружењу - изразито су повезани процесом сажимања вокалске групе -ео > - $\bar{o}$, добијене послије испадања сугласника $\kappa$ у предлошкој форми, односно префиксу преко (преко < прғко > пре > про). При томе, у резултату

${ }_{28}$ Перо Будмани, Дубровачки дијалекат, како се сада говори, 156; Милан Решетар, Der štokavische Dialekt, 109; Далибор Брозовић, Цавтат, 499; Зорка Кашић, Говор Конавала, 266; Јосип Лисац, Хрватска дијалектологија, 107.

29 Лука Вујовић, Мрковићки дијалекат, 130; Радомир Алексић, Извештај о испитивану спичанског говора, 20; Бранко Милетић, Црмнички говор, 123; Миодраг Јовановић, Говор Паштровића, 141. 
асимилације су неколика прозодијска лика: а) $n p \bar{o}$ (npō вра́та, $n p \bar{o}$ лѝваде̄, $n p \bar{o}$ ко̀се̄) које се објашњава накнадним дуљењем неновоштокавске

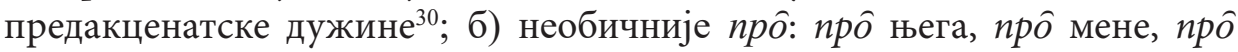
гра̀нице̄, nрô плота, $n p \hat{o}$ да̄на, $n p \hat{o}$ сијена, $n p \hat{o}$ да̄н... потврђено у говору Пиве и Дробњака (24), дијалекту источне Херцеговине (13), источној Босни (Ијекавскочтокавски говори источне Босне, 55), околини Колашина (75), србијанском Полимљу (216) и Конавлима (266), које се схвата као резултат старог преношења, а које се аналогијом уопштило и у овим новоштокавским говорима ${ }^{31}$; в) прó: npó Таре̄, npó куће̄, nрó Дрине̄, nрó села - најчешћа варијанта која одликује и најзападније новоштокавске говоре $\mathrm{e}^{32}$.

Факултативности промјене $e(\kappa) o>\bar{o} / o / \hat{o} / o$ доприносе и примјери у којима, након редукције интервокалног $\kappa$, није долазило до асимилације: прео̀ куће̄, прео̀ њивё (дакле, предлог преко реализује се у три фонетска лика: преко, прео и про); а у говору околине Колашина, у предлогу преко, обично се чује редуковано и неслоготворно e: $n p^{e} \grave{o}$ Таре (стр. 75).

Вокалска група -иo.

Процеси асимилације ове вокалске групе спријечени су развијањем секундарног $j$, које је у већини говора нешто пасивније артикулације зато се, у зависности од чујности карактеристичног шума при изговору овога гласа, од говора до говора различито обиљежава. На примјер, у дурмиторским говорима Пиве и Дробњака (43) и Ускока (254), говорима србијанског Полимља - стр. 218 , те говорима источне Херцеговине (Асим Пецо, Говор источне Хериеговине, 85) графичка ознака овога гласа

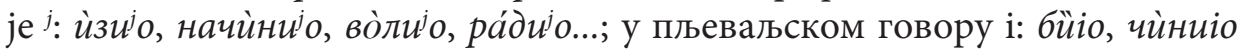
(стр. 82) $)^{33}$.

Премда је изговор сонанта $j$ између $u$ и $o$ позиционо условљен, има дијалектолога који сматрају да процеси -ио $>-u^{j} о$ у појединим говорима и не морају бити радикално спроведени. У говору Лепетана: стӓвио (62), подрӓнио (63), рӧдио $(76,93)$, нӧсио (95) / лйјо (134) и говору околи-

${ }^{30}$ В. Мирослав Николић, Говори србијанског Полимла, 216. Ипак, вокал $о$ у овом говору, као резултат регресивне асимилације, и не мора бити обавезно дуг: $п р о$ нёкй гра̀нйћа̄, про оेније њиิва.

${ }_{31}$ Мато Пижурица, Говор околине Колашина, 75.

32 Драгољуб Петровић, Говор Баније и Кордуна, Матица српска - Просвјета, Нови Сад - Загреб 1978, 74; Милорад Дешић, Западнобосански ијекавски говори, СДЗб ХХІ, Београд 1976, 162-163.

${ }_{33}$ У говорима зетско-јужносанџачког типа скала ознака за обиљежавање прелазног гласа $j$ који раздваја финалну секвенцу -ио још је разноликија: ${ }^{a} i,{ }^{a} \mathcal{u}$, ${ }^{a j},{ }^{j}, j,{ }^{a u}$. 
не Колашина: срйо / сйјо, стӥјо (стр. 171) налазе се потврде за обје варијанте - измијењену и неизмијењену ${ }^{34}$. И то, ако се глас $ј$ изговори, онда има пуну и изразиту артикулацију - таквим га сматра Данило Вушовић: бӥјо, вйдијо, али само у једном дијелу дијалекта источне Херцеговине, у Опутним Рудинама код Билеће (22), док је у другим дјеловима ове говорне зоне пасивније артикулације. У закључку, изгледа да је неспорно да степен артикулације гласа $j$, који раздваја вокале $u$ и $o$, зависи и од индивидуалних карактеристика говорника, прецизности и брзине говоpa, а понекад и од неких других чинилаца. Због тога појава хијатског $j$, и сва објашњења везана за њега, далеко превазилази простор црногорских новоштокавских говора.

Како смо и претпоставили на почетку истраживања, у говорима сјеверозападне Црне Горе јако је изражена тенденција избјегавања изговора вокалских група на крају ријечи. Склоност промјени, и то најчешће асимилацијом, највише показује вокалска група -ао, али и друге финалне секвенце које се састоје од различитих вокала (-ео, -уо, -иo) до чијег елиминисања, поред асимилације, долази и развијањем секундарних гласова $j$ и в (посебно $j$ ). Досад у дијалектолошким радовима нијесу биле уцртане прецизне изоглосе простирања наведених појава. Осим тога, показали смо да су основни односи -aо > -о у сјеверозападној Црној Гори, - $а$ o >- $a$ у југоисточној донекле поремећени све већим продором језичких црта зетско-јужносанџачких говора у црногорске новоштокавске говоре. Зато смо у понекад замршеним односима, у укрштању различи-

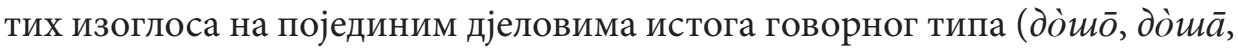
до̀шао) тражили одређене правилности и системе. Но, ниједна црта није значајније нарушила компактност црногорских новоштокавских говора, нити прекинула њихове везе са генетски и структурно сродним говорима у окружењу.

${ }^{34}$ Потпуно другачију слику, јединствену међу црногорским говорима, пружа један архаични приморски говор области Мрковића код Бара у којем се међувокално $j$ у позицији између $u$ и $о$ веома ријетко развија, у чему Лука Вујовић види рефлектовање старог стања, које мрковићки говор, јер се налази на дијалекатској периферији, чува боље од сваког другог црногорског говора (190-191, 266). 
Miodrag Jovanović

\section{FINAL SEQUENCES OF TWO DIFFERENT VOWELS IN MONTENEGRIN NEW-ŠTOKAVIAN DIALECTS}

\section{Summary}

Less frequent presence of the final vowel groups, due to the harmonization of articulation towards the first vowel (so called: progressive articulation), or towards the second vowel (so called: regressive articulation) thus represents a distinguishing characteristics of the Montenegrin dialects, as present among the folk dialects. In addition, vowel sequence ending in -ao (which, in most cases occured due to the alteration of $l$ into $o$ at the end of a syllable), due to the frequency of use of the words in which it exists and due to the common distribution, tends to be the most interesting vowel group used.

We have established that in the dialects in the Northern-Western part of Montenegro, i.e. in the so called new-štokavian dialects, the vowel group -ao usually comes down to the vowel - $o$ only (dòšo, pòš $)$. However, that situation cannot be widely applied to all the dialects, as in certain dialects, apart from the assimilation of - $a o$ into $-o$, we can often hear the results of the progressive assimilation as well ( dòs $\bar{a}$, rëk $\bar{a}$ ), especially close to the area where Zeta-South Sandzak dialect is widespread. However, althought the situation where the vowels $-a$ and $-o$ respectively in the end of a word become unassimilated, is quite unusual, it tends to be common in almost all dialects.

In addition, the analysis of rich and interesting dialects' structures also includes the occurrence of other vowel groups in the end of the words (such as: - $u$, $-e o$ and -io). 